\title{
Lights, Camera, Action! English learning through drama ${ }^{1}$
}

\section{iLuces, cámara, acción! Aprendizaje del Inglés a través del teatro}

\author{
Wendy Gorena Becerra Carvajal ${ }^{2}$ \\ Universidad Pedagógica y Tecnológica de Colombia - Tunja \\ wendy.becerra@uptc.edu.co \\ Daniela Lucia Alfonso Colmenares ${ }^{3}$ \\ Universidad Pedagógica y Tecnológica de Colombia - Tunja \\ lucy3096@gmail.com \\ Brayan José Forero Gómez ${ }^{4}$ \\ Universidad Pedagógica y Tecnológica de Colombia - Tunja \\ brayanfogo94@gmail.com \\ Lina Katherine Barón Beltrán ${ }^{5}$ \\ Universidad Pedagógica y Tecnológica de Colombia - Tunja \\ linakatherinebaron@hotmail.com
}

Received: February 28, 2017

Accepted: June 14, 2017

How to cite this article (APA, 6th ed.): Becerra-Carvajal, W., Alfonso-Colmenares, D., Forero-Gómez, B., and Barón-Beltrán, L. (2017). Lights, Camera, Action! English learning through drama. Enletawa Journal, 10 (2), 49 - 60

1 Pedagogical experience.

2 Wendy Gorena Becerra Carvajal graduated from Guillermo León Valencia school in 2011. She studied Modern Languages at Universidad Pedagógica y Tecnológica de Colombia, UPTC. She has attended to "15th Teachers' Moot and 7th Graduates Reunion" and "17th Teachers' Moot and 9th Graduates Reunion "at UPTC. She is participant of Cultural Care Au Pair as intercultural exchange 2017-2019, where she has attended to ESL and American Culture courses at Community Colleagues in Massachusetts. Her educational concerns are about ESL and intercultural approach.

3 Daniela Lucia Alfonso Colmenares graduated from Jaime Campos Jácome school in Macanal, Boyacá in 2012. She studied Modern Languages at Universidad Pedagógica y Tecnológica de Colombia, UPTC. She has attended to the 50th, 51st and 52nd ASOCOPI Annual Conferences. Her research interests are related to the use of art as a tool of teaching English Language.

4 Brayan José Forero Gómez studied Modern Languages at Universidad Pedagógica y Tecnológica de Colombia, UPTC. He is a teacher-researcher and is currently studying the Educational Management specialization at the same institution.

5 Lina Katherine Barón Beltrán studied Modern languages teaching at Universidad Pedagógica y Tecnológica de Colombia, UPTC. Her research interests focus on the body as an instrument of expression. Thus, she not only takes satisfaction in the use of drama for helping students to learn English language, but also she enjoys working with performance art for symbolizing what the mind, body, and soul yearnings. She loves reading and learning. 


\begin{abstract}
Over the past few years, learning English has gained significant importance throughout Colombia. In order for students to accomplish proficiency in this language, different strategies and methodologies are used to help improve their basic language skills. This article explores the use of drama as a strategy to develop two basic English language skills: reading and speaking. Additionally, social relationships among eleventh graders at a public institution are examined. Values, such as leadership, and the use of voice, body language, concentration, and shyness displayed during the activities were analyzed among the students. The most relevant findings form this experience are presented and described as a way to encourage teachers and students to think of drama as a useful pedagogical strategy applicable not only in linguistics, but in social and personal fields as well.
\end{abstract}

Keywords: Drama, English language, speaking skill, reading skill, social relationships, leadership, voice and body language.

\title{
Resumen
}

El aprendizaje del inglés ha venido tomando importancia en Colombia desde los últimos años. Los estudiantes necesitan ser proficientes en este idioma, usando diferentes estrategias y metodologías que pueden ayudarles para mejorar sus habilidades básicas. Este artículo explora el rol del teatro como una estrategia para desarrollar dos de las habilidades básicas del inglés: lectura y escritura; así como las relaciones sociales entre los estudiantes de grado once de una institución pública. Además, los valores adicionales que esta estrategia puede generar en estudiantes al momento de trabajar en ella. De esta manera, se presentan los resultados y conclusiones de la experiencia, con el fin de motivar a los docentes e incluso estudiantes a pensar al teatro como una estrategia pedagógica útil que puede ser aplicada no solo en la parte lingüística, sino también en los campos personal y social.

Palabras clave: teatro, aprendizaje del inglés, lectura, habla, relaciones sociales, liderazgo, uso de la voz y del cuerpo. 


\section{Introduction}

Nowadays, due to cultural and economic reasons, English has become one of the key facets in Colombian education. Since the country needs to be connected to the world, English has become a useful instrument in achieving this goal. The Ministry of Education (2014) argues that "El manejo de una lengua extranjera es sin duda una habilidad que empodera a los individuos, les brinda mayores oportunidades de acceso al conocimiento y a otras culturas y los hace más competitivos $^{6 \prime \prime}$ (p. 2). This is not an easy task because educational institutions have a set limitations and obstacles that make learning and using English more difficult for students. In Colombia, most English curricula do not take into account the use of different methods to benefit learners at the time of language input. However, this problem is not just related to linguistic aspects. It is also apparent in the relationships students establish among themselves. At times, the academic context is limited by strict rules in the use of the language without considering that learners might not be able to express themselves due to a lack of self-confidence.

For this reason, we must identify strategies that combine English learning with relationship management. This paper reflects how drama, or theatrical arts, can meet this need taking into account that

6 "The use of a foreign language is without a doubt an ability that strengthens people. It gives them the opportunity to access knowledge and other cultures, it also makes them more competitive." Translation done by the authors. people can create links between learning and social relationships. As Andrade (2007) mentions, "entendamos que para hacer teatro, hay que estar dispuestos a trabajar en equipo ${ }^{7 \prime \prime}$ (p. 90). Drama is a useful strategy in any kind of subject. In this case, learners feel free and uninhibited to express themselves through different identities.

Consequently, these role games help students understand and recognize foreign language linguistic patterns easily when they need to read and write in specific situations. Furthermore, this is a dynamic activity which integrates important values, leadership, voice and body movement, concentration and relationship improvement.

\section{Theoretical framework}

Drama is a great tool that can be used in the process of transforming education from a static procedure to a dynamic one, as well as answering the needs that each context may have. In the current section, some theories and statements are presented by authors such as Aristotle, Dryden, and Bachman in the field of drama as both an artistic representation and a pedagogical strategy proven to help students overcome difficult obstacles in their learning process.

\section{Drama}

There are many definitions that can be considered when talking about drama. Taking into account that this concept can

7 "understand that for being part of theater, it is necessary to be willing to work cooperatively." Translation done by the authors. 
have different perceptions or conceptions, it is necessary to analyze its different facets. Ryan and Kehoul (2016), who define the word's etymological origins, argue that "Drama is an Ancient Greek word meaning 'act' or 'deed'." Given that the origin of this word comes from the Ancient Greeks, we can say that drama has been part of many cultures since then. In fact, the famous philosopher Aristotle (as cited in learning to learn, 2016, para. 1) used the term "to describe poetic compositions that were 'acted' in front of audiences in a theater".

Consequently, it is pertinent to quote Dryden, who defines drama as the "Just and lively image of human nature, representing its passions and humors, and the changes of fortune to which it is subject, for the delight and instruction of mankind" (as cited in Literary Theory and Criticism, 2012, para. 1). From Dryden's statement, it is possible to perceive drama as having an internal meaning. In other words, drama helps people become conscious of the division between internal and external emotions and be able to express them without fear or shame. In this way, drama can be conceived as a means of catharsis that can enable human beings to feel free and redeemed.

\section{Drama as a pedagogical tool}

Drama helps students practice the language by using it in real-life situations and contexts. Additionally, it encourages students to freely express their feelings and personalities by reducing the pressure and fear of being criticized or judged.

In order to specifically address the pedagogical approach of drama, it is nece- ssary to take into account that it has been applied and used previously by different authors. "Drama-based pedagogy (DBP) uses active and dramatic approaches to engage students in academic, affective and aesthetic learning through dialogic meaning-making in all areas of the curriculum" (Dawson \& Lee, as cited in Drama Based Instruction-DBI- Network, 2017, para. 1). Drama-based pedagogyDBP- is not a new term in education. It has been tested and proven by authors who have discovered that it is absolutely useful at the moment of teaching and practicing different areas of knowledge. "DBP is a collection of teaching tools (including activating dialogue, theatre games as metaphor, image work, and role work) designed to be used in conjunction with classroom curriculum." (DBI Network, 2017. para. 2). Therefore, drama in the field of pedagogy can be used as a beneficial tool that can be applied in classroom practices not only to learn English, but also for different subjects that are sometimes difficult to teach.

\section{Speaking skill}

Given the importance of having speaking skills in communication, it is necessary to review this concept. "Speaking is an interactive process of constructing meaning that involves producing and receiving and processing information" (Brown, 1994; Burns and Joyce, 1997, as cited in Maryann, 1999, para. 3). Based on the information suggested by Brown, it is possible to witness how speaking skills combine different processes in order to achieve effective 
communication. Speaking implies effective listening and attention processes in order to arrive at a message that expresses exactly what the speaker needs to say.

\section{Reading skill}

Reading skills are necessary tasks in human communication. In fact, reading and reading skills have been used as one of the most relevant resources to maintain information between people and generations. Reading skills are different from speaking skills as they let the reader review and analyze the message as much as he/she needs. In this way, it also implies that the reader has enough comprehension and attention to do so. Reading is the skill that allows learners to explore knowledge in a systematized way. According to Perfetti (2001), "reading skill is an individual's standing on some reading assessments. Skilled readers are those who score above some standard on this assessment; readers of low skill are those who score under some standards" (p. 2). Based on this statement, it is pertinent to point out that people are classified in order to determine the reader's ability to understand what is being read. If the reader is able to interpret the message successfully, his/ her ability will be categorized as being high. On the other hand, if a person does not understand the message clearly, their reading level will be considered low.

However, the standard of a reader cannot be determined only based on assumptions and isolated results. There are some features that define why a reader can or cannot understand the written code. "Reading processes depend on the language of the reader and the writing system that encodes that language" (Perfetti, 2001, p. 2). In this way, reading skill is very closely related to writing skill and the way in which the text is presented. Additionally, the language used, the expressions, the degree of difficulty and other features should be considered in determining whether a reader will or will not comprehend what us said.

In a similar way, reading skills are connected to drama. When actors are preparing their performance, they should identify and understand the code presented in the script. Drama reading requires a significant amount of focus. The actors need to not only comprehend the text, but also feel every word spoken in order to give meaning to the reading. If this is achieved in the classroom, it is probable that students could improve their reading comprehension, explore their own feelings, and even foster relationships among students. This is because when students have a common goal, they become involved in performing a specific task.

\section{Methodology}

One of the most decisive aspects in the development of this experience is the way in which the methodology is oriented. In this case, it utilizes a qualitative approach. This is because its main focus was to analyze different behaviors and attitudes displayed by the students. The qualitative approach makes use of data collection without numerical measurements in order to discover or refine research questions in 
the process of interpretation (Sampieri, 2006, p. 7). This approach provides the opportunity to shape and reshape the study in the process of developing it. In the case of this experience, the approach is qualitative becauseit is entirely founded on upon the interpretation and descriptions made by the researchers based on the use of drama as a tool to overcome different issues in a group of participants.

In addition to being a qualitative study, this project also utilizes an action research approach. "Action research is a process in which participants examine their own educational practice systematically and carefully, using the techniques of research" (Ferrance, 2000, p. 1). Action research is a practical strategy that makes it possible to contribute to the improving the conditions of a given environment.

The current experience was oriented by the features of action research because the main goal of the researchers was to contribute to the opportunities that students have at the time of learning English. The idea was to help students and the institution, while becoming part of their development and improvement by using drama as the main tool.

\section{Data analysis procedure}

Instruments. Questionnaires, field notes, video recordings and interviews were used to collect data; these instruments allowed us to gather the required information for this study. In terms of data analysis, the method that was used is called triangulation. Camacho (as cited in Camacho, 2008, p. 145) provides the following definition to better understand what triangulation is: "Esta técnica recoge y analiza datos desde diferentes ángulos para establecer comparaciones entre sí. Es un control cruzado entre diferentes fuentes, por ejemplo, entre personas, documentos, instrumentos, etc." 8 This method was also used to propose different categories in which the information was classified, organized, and analyzed.

Population and participants. The population was made up of eleventh graders from a public school in Tunja, Boyacá. Their ages range between fifteen and nineteen years old. The sample is composed of ten eleventh grade students: five females and five males.

\section{Data Analysis}

The teacher-researchers found three common patterns that were used to establish three main categories in order to organize the information. A series of evidences were collected which allowed the researchers to identify the students' learning process. Table 1 better explains the emerging categories and subcategories of this study:

\section{First Category: The artistic represen- tation of the language}

The use of theatre is fruitful when working with linguistic aspect. Drama structures provide a powerful way of

8 "This technique takes and analyzes data from different perspectives in order to establish comparisons. It is a crossed control among different sources, for example, among people, documents, instruments, etc." Translation made by the authors. 


\begin{tabular}{|c|c|c|}
\hline NUMBER & CATEGORIES & SUBCATEGORIES \\
\hline \multirow[t]{2}{*}{1.} & \multirow[t]{2}{*}{$\begin{array}{l}\text { The artistic representation of } \\
\text { the language. }\end{array}$} & $\begin{array}{l}\text { 1.1 Our mouth says what the art ex- } \\
\text { presses. }\end{array}$ \\
\hline & & 1.2 Actors reading beyond the lines. \\
\hline 2. & Performing to link life. & \\
\hline 3. & $\begin{array}{l}\text { Drama and other magic } \\
\text { sparks. }\end{array}$ & \\
\hline
\end{tabular}

Table 1. Emerging categories and sub-categories

putting language into action. It gives students the opportunity to become physically and linguistically part of the story by taking on the roles of the characters and imagining that they are facing the same problems themselves (Holmwood, 2014). Consequently, this category was created to determine whether or not students could really improve their skills throughout the workshops and activities leading to a final presentation and contest.

First Subcategory: Our mouth says what the art expresses. The most relevant problems that students presented at the beginning of the process, as seen in the video recordings, were their lack of clarity and confidence when talking. In this way, it is necessary to look at how drama might have changed or improved confidence and clarity among the students. As expressed by Clipson (2013):

Drama can facilitate a whole range of purposes for which speaking might be needed by offering roles, situations, contexts and a variety of approaches to setting these up. In drama pupils can learn to use talk, and they can also learn about talk. Involvement and interaction are crucial components of the development of talk; drama can offer both these things. (p. 66)

We found that drama is an important strategy when working with speaking skills in English. Through drama, the participants had the opportunity to reenact real-life scenarios/situations from different perspectives and positions. Therefore, the students' ability to use the language was improved. Thus, it is crucial to take into consideration the participants' opinion of the participants who felt they had improved in this skill:

Pues, yo inicialmente, eh... no me iba muy bien en el inglés... eh entendía poco la, sí el léxico y el speaking, era tenaz, terrible y pues a lo largo de la obra fui mejorando y pues ya puedo hablar mejor en inglés, y pues ya aprendí nuevos términos y me ha ayudado bastante. (Interviews, Student 3)

[Well, I initially, eh....no, I didn't do very well in English...eh I didn't understand the, if the lexicon and the speaking, it was awful, terrible and well throughout the play I started improving and well, no I can speak better in English. And well, I have learned new words and it has helped me a lot.] 
One relevant aspect that was necessary to develop in order to improve speaking skills was phonetics because it was a vital part that students needed to work with the script. Students received a worksheet with the vowel sounds that they had to learn, such as [i], [ai], [y], and [i:]. Then, they had to read the words and recognize the sounds presented. Through this activity, students feltengaged. They showed comprehension and improvement in differentiating the sounds and pronouncing them.

By the end of the activity, students could recognize most of the vowel sounds and pronounce them. This helped students overcome the issues they were having. This is evident in the data collected at the beginning of the study and the results obtained after the activity was completed.

\section{Second subcategory: Actors reading} beyond the lines. Besides the lack of clarity and confidence in speaking, students also felt insecure in reading because they could understand the script or the intention beyond each line read. Once again, drama was a essential tool in aiding the improvement of reading skills, while diminishing the effects of insecurity among the students. Güngör (2008) stated that "through drama, students not only read what is in a text but also actually 'live' in it, a process that will lead to better comprehension and retention" (p. 3).

Because of this, students had significant advancements in the diverse aspects of the language, such as pronunciation, intonation, confidence at the time of talking, and reading skill. This evolution was possible thanks to the implementation of drama as a strategy.

\section{Second Category: Performing to link life}

One of aims in this study was to explore the role drama could have in improving relationships among the participants. This category was chosen with the purpose of exploring the contributions that drama could have in this field.
El teatro es un arte comunitario enraizado en el quehacer histórico de toda sociedad y es, por tanto, consustancial al ser humano, en el cual preexiste in instinto de teatralidad que le permite establecer relaciones con su comunidad, interrelaciones de hombre y sociedad por medio de manifestaciones espontaneas, actitudes y ceremonias. ${ }^{9}$ (Andrade 2007, p. 90-91)

In this way, it is possible to see how drama is a good strategy in developing social relationships. For this reason, students manifested that they really felt progress in establishing the link between drama and social relationships:

Pues, esta obra más que todo nos enseñó la unión, porque no dependemos solo de nosotros mismos sino dependemos también de los demás, $y$ aprender también que no nos tenemos que dejar solos porque en cualquier momento en la escena no depende solo del que está actuando en ese momento, sino de todos, porque nosotros también hacemos el entorno de esa persona, y en si es como un apoyo porque si nosotros estamos bien, esa persona va a estar bien, y si es... ella lo está pues nosotros también lo vamos a estar. Entonces hay bastante unión en ese sentido. (Interviews, Student 7)

9 "Theatre is a community art rooted in the historic endeavor of each society, so, consubstantial to the human beings, in which pre-exists an instinct of showmanship that let them establish relationships with their community, interrelations between men and society through spontaneous manifestations, attitudes and ceremonies." 
[Well, this play, above all, has taught us unity because we do not depend on ourselves solely, instead we depend on others as well and learn that we don't need to be alone because during the scene, it doesn't depend just on the person acting at the moment, but on everyone, because we set the stage for that person. And in fact, it is like a support because if we are doing well, that person will be fine as well, and if they are....she is, we are going to be as well. So, there is a lot of unity in that sense.]

In this sense, it is possible to see how students felt committed to helping others throughout the process. They started feeling that rehearsals were moments not only to practice English and prepare for the play, but also enjoy being friends and learn from each other. In addition, by interacting with the rest of the group, students felt that they could be better people. In other words, they felt like they could learn diverse social aspects and not just academic facts and becomenew people based on new experiences, attitudes, and support from others.

Bueno pues, eh... bueno lo que trata el teatro, tal veznos sirvió para unirnos comoequipo, trabajar duro, eh... hubieron muchas dificultades pero eso nos sirvió para unirnos, para conocernos para aprender uno del otro y seguir creciendo como personas. (Interviews, Student 5)

[Well, eh....well what they theatre was about perhaps helped us become united as a team, work hard, eh... there were many difficulties but that helped unite us so we could get to know each other and learn from one another and keep growing as people.]

Therefore, it is important to highlight that drama, in this case, is not just a pedagogical tool because students can link themselves through experiences and learn from each other by trying to overcome different issues using work-group as a main strategy.

\section{Third Category: Drama and other magic sparks}

The third category was created in order to explore the additional values that students enhanced during the drama process. During the development of the study, we found that the students were not only working on linguistic aspects, but they also developed different skills that could be useful for their lives. Some of the skills they worked on included: leadership, voice and body management, concentration and overcoming shyness.

First of all, it was possible to see how students developed leadership skills in the workshops and rehearsals. This ability can be developed with the use of drama. As Cabrera (2014, p. 12) points out, "el líder, al igual que el actor debe saber desenvolverse y ser aceptado por su audiencia."10. Leadership was one of the values included in the workshops applied, and students showed the initiative needed to improve this skill.

Another relevant aspect developed during the workshops and rehearsals was voice and body management. The use of drama allowed students to liberate their voice and bodies. They were able to set aside the fear and pressure of being observed, and in this way, they could overcome the problem of speaking.

10 "The leader, as much as the actor, must know how to perform effectively and be accepted by the audience." Translation made by the authors 
Finally the result is being great, 2 students have improved considerably their voice use, and they were able to speak louder by following their partners' advices and suggestions. This workshop is the evidence of the abilities that students have and we can realize that they can be improving all the time. (Field notes, Workshop 5)

Concentration was also worked on and enhanced in among the students. This aspect was vital for them in order to follow the script, as well as maintain coherence and cohesion in the development of the story. According to Pfister (1991):

An additional contributory factor in the concentration principle is the fact that, in dramatic texts, the sociological and psychological influences on the circumstances surrounding the story cannot be treated with quite the same breath as is possible in narrative texts. (p. 202)

So, it can be seen that through the application of theatrical activities, students can improve their concentration during the process.

Finally, it is necessary to talk about the step that students surmounted in terms of overcoming shyness and fear. It was evident that students overcame these issues during their performance in both the presentation and workshops. They declared that they felt they had improved after developing the workshops:

Bueno, por lo general siempre me he considerado una persona extremadamente tímida y con las clases de teatro pues pude demostrar mis sentimientos o emociones con el cuerpo y aparte que con el inglés pues ah.... Ayude a mejorar pues, la parte de lingüística. (Interviews, Student 2)
[Well, in general, I have always considered myself an extremely shy person, and with the theatrical classes, I can demonstrate my feelings and emotions with my body and in terms of English, well, ah...It helps to improve, well, the linguistic part.]

According to student 2, it is possible for students to feel motivated and overcome the fear of speaking that arises when presenting. Not only did students overcome their fear of performing in the drama, but also their shyness in speaking in English. Such activities allowed the students to discover the importance of motivation and interest in their activities:

Me doy cuenta que nada es imposible, que, si lo pude hacer y que la cuestión es de motivación $y$ de intentarlo, no rendirse. (Interviews, Student 7)

[I have come to realize that nothing is impossible, that, you can do it and it depends on motivation and trying, not quitting.]

\section{Conclusions}

Drama is a pedagogical tool which gives students the opportunity to discover a different way of learning English language. This is why in the development of the current experience, participants learnt some crucial phonetic rules, such as improving pronunciation of three vowel sounds in English. These rules helped students become aware of the usefulness that linguistic systems have in the English language in order to enrich their level of English. Besides, the student-student and student-teacher interactions increased during the workshops and rehearsals due 
to the fluency and confidence gained by the learners when speaking in English.

It was seen that the use of drama as a pedagogical strategy was useful in improving relationships among the participants. This became clear throughout the process because students could not freely express themselves at the beginning due to their lack of confidence as a whole. As the video recordings show, students were able to improve this ability. However, the methodology mentioned in the project helped participants to liberate their emotions and interact with their partners in a pleasant way.

In addition to the linguistic component and social interaction, we found that drama was helpful in encouraging students to work on different values, such as leadership, voice and body management, concentration and overcoming shyness.

\section{References}

Andrade, A. (2007). Elementos de teatro. Mexico: Trillas.

Brown, H.D. (1994). Teaching by principles: An interactive approach to language pedagogy. Englewood Cliffs, NJ: Prentice Hall Regents.

Cabrera, J. (2014). ¿Son las técnicas tea-trales útiles para desarrollar habilidades de liderazgo en directivos de empresa? Madrid: Universidad Pontificia de comillas. Retrieved from: https://repositorio.comi llas.edu/ rest/bitstreams/335/retrieve

Camacho, B. (2008). Metodología de la investigación científica. Tunja: Univer- sidad Pedagógica y Tecnológica de Colombia.

Clipson, S. (2013). Teaching Primary English through Drama: A practical and creative Approach (2 ${ }^{\text {nd }}$ ed.). London: Routledge, Taylor \& Francis group.

DBI Network. (2017). Drama- based instruction. Texas: University of Texas at Austin. Retrieved from: http://dbp. theatredance.utexas.edu/about

Dryden, J. (2012). Definition of drama. Bhavnagar, India. Literary theory and criticism Retrieved from: https:// sites.google.com / site/nmeictproject/ reflections/2-2-1-definition-of-drama

Ferrance, E. (2000). Action Research. Providence, Rhode Island: Brown University. Retrieved from: https://www. brown.edu/academics/educationalliance/sites/brown.edu.academics.education-alliance/files/publications / act_research.pdf

Güngör, A. (2008). Effects of drama on the use of reading comprehension strategies and on attitudes towards reading. Florida. Journal for learning through the arts, 4 (1). Retrieved from: https://escholarship.org/uc/ item/4d62r6p9

Holmwood, C. (2014). Drama education and drama therapy. Exploring the space between disciplines. New York: Routledge, Taylor \& Francis group.

Ministerio de Educación Nacional de Colombia. (2014). Plan nacional de inglés "Colombia very well". Bogotá: MinEducación.

Perfetti, A. (2001). Reading skills. International encyclopedia of the social E behavior- 
al sciences. Oxford: Pergamon. Retrieved from: http://www.pitt.edu/ perfetti/PDF/Reading\%20skills.pdf

Pfister, M. (1991). The theory and analysis of drama. Cambridge: Cambridge University.

Ryan, D. and Kehoul, G. (2016). What is drama? Australia. Learning to learn in drama. Retrieved from: https:// resource.acu.edu.au/learndrama/ what_drama.htm

Sampieri, R. (2006). Metodología de la investigación. Mexico: McGraw Hill. 